\title{
Investigation of the mycelial compatibility of Macrophomina phaseolina
}

\author{
Kitti Csüllög*, Gábor Tarcali \\ Institute of Plant Protection, Faculty of Agricultural and Food Sciences and Environmental Management, \\ University of Debrecen, H-4032 Debrecen, Böszörményi út 138, Hungary
}

\begin{abstract}
CsüllöG, K., TARCALI, G., 2020. Investigation of the mycelial compatibility of Macrophomina phaseolina. Folia Oecologica, 47 (2): 153-158.

Macrophomina phaseolina (Tassi) Goid. is found on all five crop-growing continents. In hot and dry seasons, this fungus is capable of causing considerable damage. In this study, mycelial compatibility of M. phaseolina isolates was investigated. In total the 30 samples collected were tested to examine their compatibility. The sunflower samples examined were collected in 2019 and 2020 in different regions of Hungary (29 isolates) and Slovakia ( 1 isolate). A total of 465 pairing tests were made with 30 isolates. The results of our examination showed incompatibility in 12 pairings. In our studies, we also measured the size of the microsclerotia of the isolates in order to determine which group they belong to. The diameter of the microsclerotia ranged from 74 to $182 \mu \mathrm{m}$. Based on this, microsclerotia belong to group ' $\mathrm{C}$ ', as well as the data of previous studies in Hungary.
\end{abstract}

Keywords

genetic variability, host plant, invasive pathogen, M. phaseolina, sunflower, vegetative compatibility

\section{Introduction}

Macrophomina phaseolina (Tassi) Goid. (Botryosphaeriaceae) [synanamorph: Rhizoctonia bataticola (Taubenh.) E. J. Butler, nowadays used as one of its synonyms] is an important plant pathogenic fungus (AMBRósio et al., 2015). The pathogen has two anamorph stages. Macrophomina phaseolina is the name of the pycnidia form. Pycnidia generally develop the host tissues. The microsclerotial stage is named Rhizoctonia bataticola, which produces microsclerotia both on stems and within the stems.

M. phaseolina is considered to be an invasive fungus, with more and more hosts and can cause huge loss of yield to many crops worldwide (DHINGRA and SinCLAIR, 1978). Under dry and risky conditions this pathogen can cause up to $100 \%$ crop loss (DAMTEA and OJIEWo, 2016). M. phaseolina has been reported in Italy (ZAZZERINI, 1980), Spain (JimenÉZ-Diaz et al., 1983), Portugal (de BARros, 1985), Romania (Ionită et al., 1996), Serbia (AćIMOvić, 1998),
Bulgaria (AlEXANDRov, 1999), Russia (YAKUTKIN, 2001), USA (GulYa et al., 2002), Czech Republic (KudLíKová et al., 2002), Slovakia (Bokor, 2007) and Turkey (МАHMOUD and BUDAK, 2011).

In Slovakia the fungus caused a high rate of sunflower infection in 2005 and 2006 (BOKOR, 2007). JIMENÉZ-DiAZ et al. (1983) estimated that the charcoal rot and losses reached $20-36 \%$ in sunflowers. VEVERKA et al. (2008) reported that one of the critical questions for further research is to know how the pathogen survives both in the soil and/ or on other hosts. The fungus overwinters by forming microsclerotia and tolerates low temperatures and can infect host plants easily in the following years (AwAN et al., 2018). In Hungary, the pathogen was observed first on sunflowers in 1970 (BÉKÉSI, 1970). BÉKÉSI (2002) reported an infection rate of $90 \%$ in sunflowers, which resulted in a loss of yield of about $30-35 \%$.

This invasive fungus has a wide host range including field crops, vegetables, trees, other herbaceous plants,

*Corresponding author: e-mail:kitticsullog@gmail.com 
weeds, and dicot or monocot plant species worldwide. $M$. phaseolina has been reported in many important plants such as Ipomoea batatas (TAubenhaus, 1913), Solanum tuberosum (AsHBY, 1927), Lycopersicon esculentum, Phaseolus vulgaris (SMall, 1928), Helianthus annuus (Mackie, 1932), Zea mays (MANeval, 1937), Cucumis melo (WiAnt, 1937), Medicago sativa (HoffMASTER et al., 1943), Glycine max (Preston, 1945), Nicotiana tabacum (REICHERT and Hellinger, 1947).

It was also found on weeds, for example Ambrosia artemissifolia (BoEwe, 1963) and Xanthium species (NIKANDROW et al., 1990), and also some ornamental plants Crinum asiaticum and Hymenocallis littoralis (HudASHAKIRAH et al., 2019).

In Hungary, M. phaseolina was reported on Zea mays (VöRÖs and MANNINGER, 1973), Glycine max (Érsek, 1979), Solanum tuberosum, Helianthus tuberosus, Phaseolus vulgaris, Vicia faba, Allium sativum (SIMAY, 1987; Simay, 1990), Beta vulgaris (KopPáNYI et al., 1993), Cannabis sativa, Valeriana officinalis (SIMAY and KADLICSKÓ, 1993), Capsicum annuum (Fischl et al., 1995), Citrullus lanatus (BÉKÉSI et al., 1995), Prunus armeniaca (VAJNA and RozSNyAi, 1995) and Picea pungens (FISCHL et al., 2008).

The pathogen is able to spread by seeds (SIMAY, 1990), or it can infect the host plants from the soil and stubble (Chaudhary et al., 2017). The pathogen causes charcoal rot, root rot and seedling blight (SMALL, 1928). Infected plants lose their vitality and wither and early death is typical (CsöNDES, 2009). When the air temperature is high around the blooming period, symptoms are dramatic and progressive on many crops (BLANCO-LOPÉZ and JIMÉNEZDiÁz, 1983). The most dangerous weather conditions are drought and high temperature, and these conditions generate water stress for the plants (MAYER-PEREZ et al., 2002). A soil temperature of $28-35^{\circ} \mathrm{C}$ is the most suitable for $M$. phaseolina infection (DHINGRA and SINLAIR, 1978). After blooming, the lower part of the stem and the top of the taproot show grey and black discoloration. Plant tissues are shredded (CsÖNDES, 2009), the stem epidermis regularly flakes away and inside the stem hundreds of microsclerotia are visible (KoLte, 1985). After infection on sunflowers the fungus can cause a decrease of 1,000 in seed weight and protein content. (KeERIO et al., 2014). In Bulgaria, the charcoal rot caused 16 to $42.8 \%$ damage in the 1990-1996 period (AlEXANDrov, 1999). Control of the pathogen is complicated because soil tillage practices and crop rotation are not effective (CHAMORRo et al., 2015).

The biology of the fungus is not yet completely known. The teleomorph stage of the fungus is unknown (PREMAMALINI et al., 2012). On Potato-Dextrose-Agar (PDA) Rhizoctonia bataticola develops only the microsclerotial form. Two different isolates of the pathogen are said to be compatible if they are capable of creating hyphal anastomoses (hypha bridges) between each other (SHARMA et al., 2016). Anastomosis means the fusion of one fungal hyphal cell with another, genetically compatible hyphal cell (de Novals et al., 2017). Through the anastomoses their genetic material migrates from one isolate to another, resulting in genetic recombination (MIHAIL and TAYLOR, 1995). If two isolates are incompatible, barrier zones or blocking zones develop between the isolates (CsöNDES, 2009). Genetic variability of the fungus is very important. If one strain of the fungus transfers its genetic material into another strain which has already adapted to certain environmental conditions new and more adaptive strains can evolve (SHARMA et al., 2016). The results of compatibility tests of $M$. phaseolina isolates were referred to only once in Hungary (CsöNDES, 2011). The main goal of this study was investigation of genetic variability and vegetative compatibility-incompatibility of Macrophomina phaseoli$n a$ among different strains. CsöNDES (2011) investigated the mycelial compatibility of 53 Macrophomina phaseolina isolates in Hungary. CsöNDES (2011) described that the most of the isolates were compatible, only 24 pairs of all the possible paired combinations showed incompatible relationships. These results suggest that the same or very similar genotypes may spread over long distances, probably through the transportation of seeds or crops contaminated with microsclerotia (CSÖNDES, 2011). In the present study we aimed also to identify the type of microclerotia of studied pathogen.

\section{Materials and methods}

Mycelial compatibility of $M$. phaseolina isolates from different locations was investigated in the laboratory. In total the 30 samples collected were tested to examine their compatibility. The sunflower samples examined were collected from 2019 to 2020 in Hungary (29 isolates) and Slovakia (1 isolate).

All of the collected sunflower stem samples were disinfected with $75 \%$ ethanol for 4-5 minutes and rinsed with sterile water. Little pieces of infected stems were placed on $15 \mathrm{ml}$ PDA media in $90 \mathrm{~mm}$ Petri dishes to culture and were incubated for 7 days at $30^{\circ} \mathrm{C}$ under dark conditions. Growing cultures were transferred on new PDA. Mycelial discs with a diameter of $0.5 \mathrm{~mm}$ were cut out from all pure cultures. Three different mycelial discs were placed in each Petri dish on PDA. In the first Petri dish samples No. 2 and 3 were added next to sample No. 1; in the second Petri dish samples No. 4 and 5 were added next to strain No. 1; and this process was continued until all strains had been evaluated. All Petri dishes were incubated for 7 days under dark conditions. After incubation the relationship between two isolates was examined. If two strains were compatible the mycelia grew into each other and produced hyphal bridges (Fig. 1) which are visible clearly by microscope. The relationship between two isolates was considered incompatible when a blocking zone or barrier was formed at the hyphal contact site.

The types of microsclerotia (Fig. 2) were investigated according to Haig's characterization (HAIG, 1929). HAIG (1929) described 3 groups of M. phaseolina microsclerotia. According to the characterization, the size of Group ' $\mathrm{A}$ ' is $1 \mathrm{~mm}$, the average size of Group ' $\mathrm{B}$ ' is $200 \mu \mathrm{m}$ and the size of Group ' $\mathrm{C}$ ' is about $120 \mu \mathrm{m}$. Randomly selected 50 microsclerotia from each pure culture were measured under a microscope, in total diameter of 1,500 microsclerotia were measured. The results for each pure culture were averaged. 


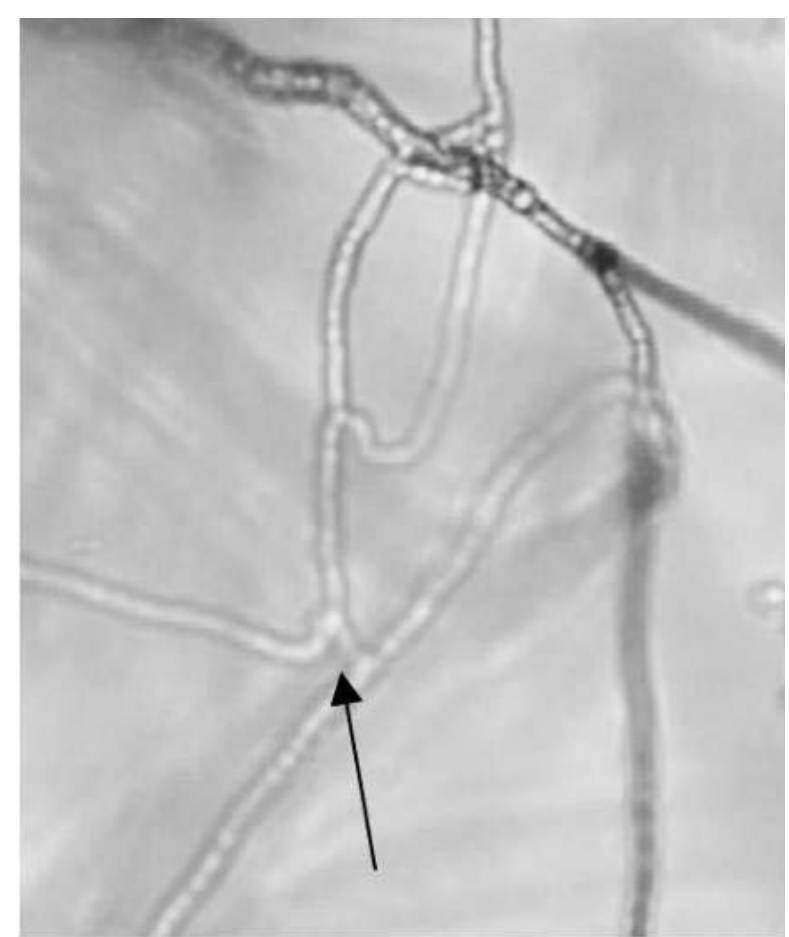

Fig. 1. Anastomosis between two compatible isolates.

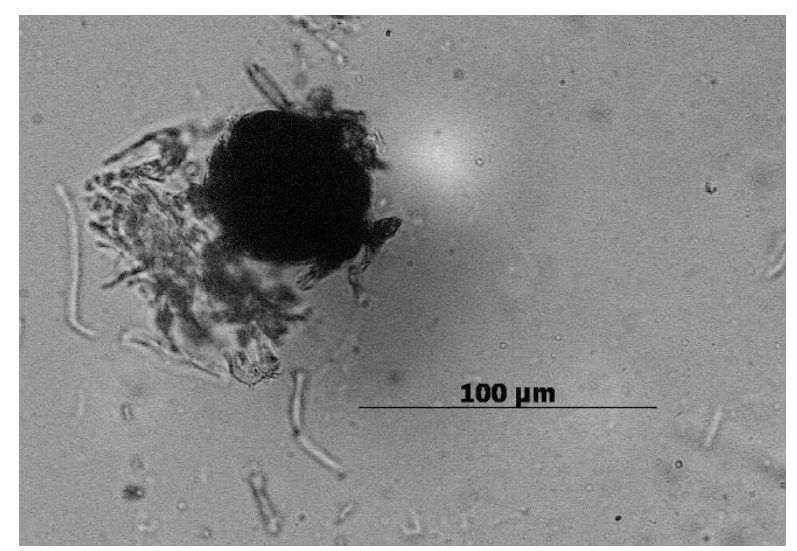

Fig. 2. Macrophomina phaseolina microsclerotium.

\section{Results and discussion}

A total of 465 pairing tests were made with 30 isolates. The results of our examination showed incompatibility in 12 pairings (Table 1 ).

Most often, isolate number 6 was incompatible with a total of 5 other isolates. Isolate number 8 was incompatible with 4 other isolates. Isolate number 6 originates from Berettyóújfalu and isolate number 8 originates from Hajdúböszörmény (Fig. 3).

The places of origin of the incompatible isolates were located far away from each other, more than $120 \mathrm{~km}$ in most cases, except for Berettyóújfalu (No. 6 in Fig. 3) and Hajdúböszörmény (No. 8 in Fig. 3) (70 km), Penyige (No. 23 in Fig. 3) and Hajdúdorog (No. 29 in Fig. 3) (80 km), as well as Berettyóújfalu (No. 6 in Fig. 3) and Körösszakál
Table 1. Incompatible pairs of tested isolates

\begin{tabular}{ccc}
\hline \multicolumn{3}{c}{ Incompatible pairs } \\
\hline $3-9$ & $6-19$ & $8-27$ \\
$6-8$ & $6-26$ & $12-13$ \\
$6-17$ & $8-12$ & $23-26$ \\
$6-18$ & $8-21$ & $23-29$ \\
\hline
\end{tabular}

(No. 19 in Fig. 3) $(30 \mathrm{~km})$. Results of previous similar studies have shown that there is incompatibility mostly between isolates far from each other. It should be noted, that 2 compatible isolates were collected close to each other (5 $\mathrm{km}$ ) from the fields of Komádi village (Komádi-1 and Komádi-2). There was one sample originating from Slovakia No. 24 in Fig. 3 from Sturovo) among the examined samples, which was compatible with all Hungarian samples.

Result of the current study is important because the teleomorph stage of the fungus is not yet known (PREMAMALINI et al., 2012), and genetic recombination can occur between two compatible strains only by hyphal bridges. Based on our research, it can be said that most of the isolates collected close to each other were compatible, while CsöNDES (2009) found that slightly different genotypes occur in areas close to each other. According to our results most of the isolates whose origins are far apart were also compatible with each other. This result verifies the theory that the microsclerotia of the pathogen are able to travel long distances. In the future, we will try to collect samples also from neighboring countries to demonstrate our theory.

In Hungary, mycelial compatibility of $M$. phaseolina was investigated only once (CsÖNDES, 2011). In this study the mycelial compatibility of 53 isolates collected from sunflower, maize and soybean in different regions of Hungary was determined (CsöNDES, 2011). Similarly most isolates were compatible, only 24 pairs of all the possible paired combinations showed incompatible relationships, even geographically distant isolates were found to be compatible (CsöNDES, 2011). In previous studies by CsÖNDES (2011), strains from Serbia were tested and all Serbian strains were found to be compatible with every Hungarian sample. The results confirmed that the fungus probably spread to Hungary from Serbia. The Slovakian isolate was compatible with all Hungarian isolates, so it is possible that the fungus spread to Slovakia from Hungary; although this theory requires further investigation.

Genetic variability of Rhizoctonia bataticola is assumed to be due to mutation, hyphal fusion and mitotic recombination (SHARMA et al., 2016). Between incompatible isolates, there is a genetic difference and this requires further molecular biological examinations as well. The genetic variability of the pathogen can also cause additional difficulties for practical plant protection. Mycelial compatibility tests were done with another pathogen of sunflowers, Sclerotinia sclerotiorum fungus in Hungary by ZÁNDOKI (2005), who identified isolates originating from a greater distance from each other generally as compatible, while there is more often incompatibility between those which are geographically close to each other. In this study 


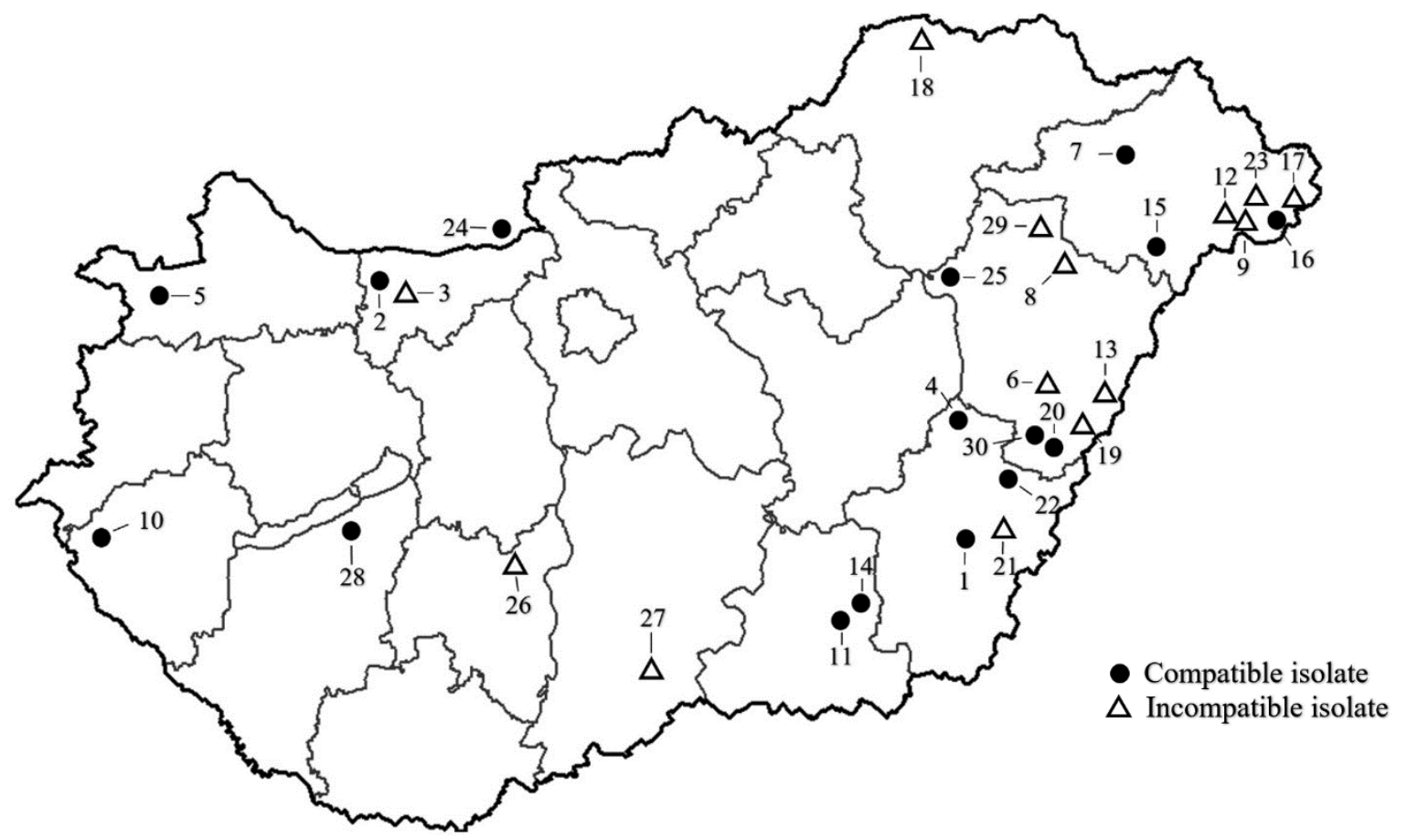

Fig. 3. Locations of sampling in different regions of Hungary and Slovakia.1, Békéscsaba; 2, Bana; 3, Bábolna; 4, Bucsa; 5, Röjtökmuzsaj; 6, Berettyóújfalu; 7, Buj; 8, Hajdúböszörmény; 9, Csenger; 10, Szombathely; 11, Székkutas; 12, Kocsord; 13, Kismarja; 14, Kakasszék; 15, Nyírmihálydi; 16, Nagygéc; 17, Zajta; 18, Rakaca; 19, Körösszakál; 20, Komádi 1st sample; 21, Doboz; 22, Vésztő; 23, Penyige; 24, Sturovo; 25, Egyek; 26, Bikács; 27, Mélykút; 28, Karád; 29, Hajdúdorog; 30, Komádi 2nd sample.

we have also pointed out that incompatible relationships can occur between strains originating from sites that are a greater distance from each other.

The diameters of microsclerotia from the studied pure cultures were in each case between 74 and $182 \mu \mathrm{m}$. The average diameter of the measured microsclerotia was 128 $\mu \mathrm{m}$. It was found that in the case of the Hungarian samples all microsclerotia belonged to Group ' $\mathrm{C}$ '. In previous study, BÉKÉSI (1970) identified in Hungary similarly the same type of microsclerotia, Group 'C'.

In summary, we can say that M. phaseolina is one of the very important invasive polyphagous pathogens for the future of crop production in southern areas of the globe as well as in Europe (TARANKATA et al., 2003). Due to global warming, the fungus spreads easily to northern areas, and its genetic variation also helps in the migration of the pathogen.

\section{Acknowledgements}

We would like to thank the Plant Protection Institute of University of Debrecen (Faculty of Agricultural and Food Sciences and Environmental Management) for providing the basic conditions and tools for the research. We would also like to thank the farmers who provided the sites for the field sample collections.

\section{References}

Aćimović, M., 1998. Charcoal root and stem rot. In Sunflower diseases. Novi Sad, Serbia: Scientific Institute of Field and Vegetable Crops, p. 544-567.

AleXANDROV, V., 1999. Incidence of charcoal rot of sunflower caused by Sclerotium bataticola Taub. in Bulgaria. Bulgarian Journal of Agricultural Science, 5: 867-870.

Ambrósio, M.M.Q., Dantas, A.C.A., Martínez-Perez, E. Medeiros A.C., Nunes G.H.S., BeléN M.P., 2015. Screening a variable germplasm collection of $\mathrm{Cu}$ cumis melo L. for seedling resistance to Macrophomina phaseolina. Euphytica, 206: 287-300.

AshBy, S.F., 1927. Macrophomina phaseoli (Maubl.) comb. nov. The pycnidial stage of Rhizoctonia bataticola (Taub.) Butl. Transactions of the British Mycological Society, 12: 141-147.

Awan, Z.A., ShOAIB, A., Khan, K.A., 2018. Variations in total phenolics and antioxidant enzymes cause phenotypic variability and differential resistant response in tomato genotypes against early blight disease. Scientia Horticulturae, 239: 216-223.

BÉKÉSI, P., 1970. A Macrophomina phaseoli (Maubl.) Ashby magyarországi megjelenése és kártétele napraforgón [Occurrence and damage of Macrophomina phaseoli (Maubl.) Ashby of sunflower in Hungary]. Növényvédelem, 7: 304-307. 
BÉKÉSI, P., 2002. A napraforgó legfontosabb betegségei és az ellenük alkalmazható védekezés lehetőségei [The most important diseases of sunflower and the possibilities of control]. Gyakorlati Agrofórum, 13 (1): 23-26.

BÉKÉsi, P., Szani, Sz., Zalka, A., 1995. A Macrophomina phaseolina (Tassi) Goid. Hazai előfordulása dinnyén [Occurrence of Macrophomina phaseolina (Tassi) Goid. of melon in Hungary]. In Integrált Termesztés a Kertészetben, 16: 107.

Blanco-LopÉz, M.A., JimÉnÉz-Diáz, R.M., 1983. Effect of irrigation on susceptibility of sunflower to the host by Macrophomina phaseolina. Plant Disease, 67: 1214 1217.

Boewe, G.H., 1963. Host plants of charcoal rot disease in Illinois. Plant Disease Reporter, 47: 753-755.

BoKoR, P., 2007. Macrophomina phaseolina causing a charcoal rot of sunflower through Slovakia. Biologia, Bratislava, 62: 136-138.

Chamorro, M., Miranda, L., Domínguez, P., Medina, J.J., Soria, C., Romero, F., LóPez-Aranda, J.M., De los SANTOS, B., 2015. Evaluation of biosolarization for the control of charcoal rot disease (Macrophomina phaseolina) in strawberry. Crop Protection, 67: 279-286.

Chaudhary, D.H., PathaK, D.M., Chaudhary, M.M., 2017. In vitro efficacy of fungicides against dry root rot (Macrophomina phaseolina) of soybean. International Journal of Current Microbiology and Applied Sciences, 6 (8): 1298-1301.

CsÖNDES, I., 2009. A Macrophomina phaseolina kárositását befolyásoló tényezők vizsgálata eltérö gazda-parazita kapcsolatokban [Investigation of the factors affecting damage of Macrophomina phaseolina in different hostparasite relationships]. PhD thesis. Keszthely, Hungary: Pannon University. $120 \mathrm{p}$.

CsöNDES, I., 2011. Mycelial compatibility of Hungarian Macrophomina phaseolina isolates. Acta Agronomica Hungarica, 59 (4): 371-377.

Damtea, T., OJiewo. C.O., 2016. Current status of wilt/root rot diseases in major chickpea growing areas of Ethiopia. Archives of Phytopathology and Plant Protection, 49: 222-238.

De Barros, L.M., 1985. Disease complex (Fusarium oxysporum and Macrophomina phaseolina) responsible for sunflower wilt in Portugal. In 11th international sunflower conference. Mar del Plata, Argentina, March 10-13, 1985. Book of proceedings. Buenos Aires, Argentina: Asociación Argentina de Girasol, p. 445-448.

De Novais, B.C., Pepe, A., Siqueira, J.O., Giovannetti, M., Sbrana, C., Brazil, M., 2017. Compatibility and incompatibility in hyphal anastomosis of arbuscular mycorrhizal fungi. Scientia Agricola, 74: 411-416.

Dhingra, O.D., Sinclair, J.B., 1978. Biology and pathology of Macrophomina phaseolina. Viçosa, Minas Gerais, Brasil: Universadida Federal de Vicosa, Imprensa Universitária da U.F.V. 166 p.

Érsek, T., 1979. Occurence of charcoal rot and anthracnose of soybeans in Hungary. Acta Phytopathologica, 14: 17-21.

Fischl, G., Csöndes, I., KadlicsKó, S., Józsa, A., 2008. Az ezüstfenyő (Pinus pungens Engelm.) vörösödését és pusztulását okozó tényezők vizsgálata [The causative agents of red discolouration and dumping off on silver spruce (Pinus pungens)]. Növényvédelem, 44: 401-402.

Fischl, G., KAdlicskó, S., Kovács, J., 1995. A Macrophomina phaseolina (Tassi) Goid. okozta töhervadás paprikán [Occurrence of wilting on pepper caused by Macrophomina phaseolina in Hungary]. Növényvédelem, 31: 589-592.

Gulya, T.J., Krupinsky, M.D., Charlet L.D., 2002. First report of charcoal rot (Macrophomina phaseolina) on sunflower in North and South Dakota. Plant Disease, 86: 923.

HaIG, J.C., 1929. Macrophomina phaseoli (Maubl.) Ashby and Rhizoctonia bataticola (Taub.) Butl. Tropical Agriculture, 23: 3-4.

Hoffmaster, D.F., Mclaughlin, J.H., Ray, W.W., Chester, K.S., 1943. The problem of dry rot caused by Macrophomina phaseoli. Phytopathology, 33: 1113.

Huda-Shakirah, A.R., Kee, Y.J., Hafifi, A.B.M., Azni, N.N.M, ZaKaria, L., MoHD, M.H., 2019. Identification and characterization of Macrophomina phaseolina causing leaf blight on white spider Lilies (Crinum asiaticum and Hymenocallis littoralis) in Malaysia. $M y$ cobiology, 47 (4): 408-414.

IONITĂ, A., ILIESCU, H., KUPFERBERG., S., 1996. Macrophomina phaseolina - one of the main pathogens of sunflower crop in Romania. In Proceedings of the 14th international sunflower conference. Beijing, China, June 12-20, 1996. Shenyang: ISA, p. 718-723.

JimenÉZ-DiAZ, R.M., BlanCO-LÓPEZ, M.A., SACKSTON, W.E., 1983. Incidence and distribution of charcoal rot of sunflower caused by Macrophomina phaseolina in Spain. Plant Disease, 63: 1033-1036.

Keerio, M., Wagan, K.H., Abro, M.A., Jiskani, M.M., IsHAQ, M.U., 2014. Investigations on the charcoal rot caused by Macrophomina phaseolina (Tassi) goid problem in sunflower and their management in Sindh, Pakistan. European Academic Research, 7: 9342-9358.

Kolte, S.J., 1985. Diseases of annual edible oilseed crops. Vol. II. Boca Raton, Florida: CRC Press, p. 33-44.

KoppáNyi, M., NAGY, J., Zsembery, S., BóDIS, Z., 1993. Új hervadásos betegség cukorrépában [New wilting disease on sugarbeet]. Gyakorlati Agrofórum, 7: 41.

Kudlíková, I., Šárová, J., Žalud, Z., Veverka, K., 2002. Neue Sonnenblumenkrankheiten in der Tschechischen Republik [New sunflower diseases in the Czech Republic]. In 53. Deutsche Pflanzenschutztagung in Bonn 16.19. September 2002. Mitteilungen aus der Biologischen Bundesanstalt für Land- und Fortswirtschaft Berlin-Dahlem, Heft 390. Berlin: Parey, p._356-357.

MACKIE, W.W., 1932. A hitherto unreported disease of maize and beans. Phytopathology, 22: 637-644.

Mahmoud, A., BudaK H., 2011. First report of charcoal rot caused by Macrophomina phaseolina in sunflower in Turkey. Plant Disease, 95 (2): 223-224.

Maneval, W.E., 1937. A list of the Missouri fungi. The University of Missouri Studies, Science Ser. 12, 3. Columbia: University of Missouri. $150 \mathrm{p}$.

Mayer-Perez, N., Gracia-Espiosa, R., Lopes-Castaneda, C., Acosta-Gallegis, J.A., Simpson, J., 2002. Water relations, histopathology and growth of common bean (Phaseolus vulgaris L.) during pathogenesis of Mac- 
rophomina phaseolina under drought stress. Physiological and Molecular Plant Pathology, 60: 185-195.

MinaIL, J.D., TAYLOR, S.J., 1995. Interpreting variability among isolates of Macrophomina phaseolina in pathogenicity, pycnidium production, and chlorate utilization. Canadian Journal of Botany, 73: 1596-1603.

Nikandrow, A., Weidemann, G.J., Auld, B.A., 1990. Incidence and pathogenicity of Colletotrichum orbiculare and a Phomopsis sp. on Xanthium sp. Plant Disease, 74: 796-799.

Premamalini, T., Ambujavalli, B.T., Vijayakumar, R., Rajyoganandh, S.V., Kalpana, S., Kindo, A.J., 2012. Fungal keratitis caused by Macrophomina phaseolina a case report. Medical Mycological Case Reports, 1 (1): $123-126$

Preston, D.A., 1945. Host index of Oklahoma plant diseases. Technical Bulletin (Oklahoma Agricultural Experiment Station), no. 21. Stillwater, Oklahoma: Oklahoma Agricultural and Mechanical College, Agricultural Experiment Station. 168 p.

Reichert, I., Hellinger, E., 1947. On the occurrence, morphology, and parasitism of Sclerotium bataticola. Palestine Journal, 6: 107-147.

Sharma, M., Ghosh, R., Pande, S., 2016. Dry root rot (Rhizoctonia bataticola (Taub.) Butler): an emerging disease of chickpea - where do we stand? Archives of Phytopathology and Plant Protection, 48: 797-812.

SimAY, E.I., 1987. A Macrophomina phaseolina (Tassi) Goid. három új gazdanövénye Magyarországon [Three new host plants of Macrophomina phaseolina (Tassi) Goid. in Hungary]. Növénytermelés, 36: 91-96.

SimAY, E.I., 1990. Adatok a Macrophomina phaseolina (Tassi) Goid. növényköréhez Magyarországon [Data for host plants of Macrophomina phaseolina (Tassi) Goid. in Hungary]. Növénytermelés, 39: 23-26.

SimaY E.I., KADLICSKó, S., 1993. A Macrophomina phaseolina (Tassi) Goidanich újabb gazdanövényei Magyarországon [The latest host plants of Macrophomina phaseolina (Tassi) Goidanich in Hungary]. Növényvédelem, 29: $27-28$.
Small, W., 1928. On Rhizoctonia bataticola (Taub.) Butler as a cause of root disease in the tropics. Transactions of British Mycological Society, 13: 40-68.

Tarankata, J., Sharma, T.R., Prasad, R.D., Arora, D.K., 2003. Molecular characterization of Macrophomina phaseolina and Fusarium species by a single primer RAPD. Microbiology Research, 158: 249-257.

Taubenhaus, J.J., 1913. The black rots of the sweet potato. Phytopathology, 3: 159-166.

VAJnA, L., Rozsnyai, Z., 1995. Macrophomina phaseolina (Tassi) Goid. és a Diaporthe eres Nitschke, mint a fiatal kajszifák elhalásában szerepet játszó gombák Magyarországon [Macrophomina phaseolina (Tassi) Goid. and the Diaporthe eres Nitschke, as fungi involved in the death of young apricots in Hungary]. Növényvédelem, 31 (2): $81-83$.

Veverka, K., Palicová, J., Kř́ížKovÁ, I., 2008. The incidence and spreading of Macrophomina phaseolina (Tassi) Goidanovich on sunflower in the Czech Republic. Plant Protection Science, 44: 127-137.

VÖRÖS, J., MANNINGER, I., 1973. A Macrophomina phaseolina (Tassi) Goid. előfordulása kukoricán, Magyarországon [Occurrence of Macrophomina phaseolina (Tassi) Goid. of maize in Hungary]. Növényvédelem, 9: 193-195.

WiANT, J.S., 1937. Investigation of the market diseases of cantaloupes and honey dew and honey ball. Technical bulletin, 573. Washington D.C.: United States Department of Agriculture. $47 \mathrm{p}$.

YAKUTKIN, V.I., 2001. Diseases of sunflower in Russia and their control. Zashchita i Karantin Rastenii, 10: 26-29.

ZÁNDOKI, E., SzŐDI, S., TurócZI, G., 2005. Mycelial compatibility of Sclerotinia sclerotiorum strains of different area. Acta Phytopathologica et Entomologica Hungarica, 40: 295-301.

ZAzZerini, A., 1980. Sunflower diseases in Italy. Helia, 3: 45-46.

Received May 17, 2020

Accepted August 18, 2020 